\title{
Heideggerian Conscience as Placebo Effect in Auster's Mr Vertigo: The Art of Life in the Face of Death
}

\author{
*MOHAMMAD-JAVAD HAJ'JARI \\ NASSER MALEKI \\ English Department, Razi University, Kermanshah, Iran \\ *Corresponding author: aminhajjari@gmail.com
}

Published online: 31 October 2019

To cite this article: Mohammad-Javad Haj'jari and Nasser Maleki. 2019. Heideggerian conscience as placebo effect in Auster's Mr Vertigo: The art of life in the face of death. KEMANUSIAAN the Asian Journal of Humanities 26(2): 81-104, https://doi.org/10.21315/kajh2019.26.2.4

To link to this article: https://doi.org/10.21315/kajh2019.26.2.4

\begin{abstract}
The voice of conscience, in Heideggerian existentialism, stands for humanity's inherent potency to call himself into an authentic way of living. Heidegger, through this concept, calls us to acknowledge the range of our possibilities in life before death than regret what we have already done. Since authentic living is a process than an end - no salvation being possible in this world - being sensitive to the call is trying to be authentic throughout life. As such, the call acts like taking placebos which keep us hopeful while we are in bad health, although there might be no cure. Paul Auster's Mr Vertigo, being a novel filled with existential themes, can be read to concretise the existential intonation of Heideggerian conscience, following Auster's own existential outlook into the human condition. This paper, by applying an interdisciplinary approach, thus reads $\mathrm{Mr}$ Vertigo in the light of Heidegger's certain existential concepts and the implications they have concerning how our existential conscience has a placebo effect. As such, this paper is to argue that Auster's Yehudi in Mr Vertigo plays the role of Walt's voice of conscience to help him with an authentic life style, the novel meanwhile highlighting how the call of conscience can help Heidegger's "Dasein" with the infinity of possibilities it has before death in a world determined by contingency.
\end{abstract}

Keywords and phrases: Auster, conscience, Heidegger, Mr Vertigo, placebo effect

\section{Introduction}

Paul Auster's Mr Vertigo (1994), the life story of Walter Claireborne Rawley and his attempts to cope with life under the guidance of his mentor Master Yehudi, is a story of hopefulness in the face of alternative failures and victories. Walter's life, from his early poverty in his uncle's house to his prosperity in old age following his acqiuntance with Master Yehudi, is not just a course of life as seen in a traditional 
Bildungsroman or novel of education. Mr Vertigo highlights one's understanding of one's possibilities in life in an existential manner, that is, Auster in this novel gives us a full portrait of an artist who depicts his own life before himself and makes his life meaningful.

Walter's ability to levitate, which gives the work an "element of illusion" (Brown 2007, 106), is the cause of "skepticism and incredulity" for readers since distinguishing Walter's "storytelling and self-invention" is not possible (Martin 2008, 23). Levitation in the air has in fact flavored the novel with magic realism, as no character in the novel ever doubts the unreal aspect of Walt's levitating abilities. Moreover, Walter describes his adventures "with complete seriousness, complete plausibility" (Barone 1995, 20) - in Walt's words, "Every word in these thirteen books is true" (Auster 1994, 275). Nevertheless, as Auster holds, "levitation is a metaphor" (Auster and Siegumfeldt 2017, 180), and the novel is "a realist book", excluding the "improbable" element of "levitation" which, Auster recommends, "we must obviously accept" for everything else in the novel to hold true (as cited in De Cortanse 1997, 81). Levitation in Mr Vertigo is a mega-metaphor for humankind's possibilities of action, especially when we observe a young beggar who ends up as a decent wealthy old man only through the guidance of a master who symbolically represents the voice of conscience in an existential sense. In the light of Heidegger's existentialism, those who are not lost in their everydayness and open their eyes to their possibilities away from stagnancy and nihilism have heard a voice within which calls them to action. Thus Walt's life can be interpreted as a process of learning to live authentically, as Heidegger delineates it through Being and Time.

Walt's life under the guidance of Yehudi highlight humankind's attempt to lead an authentic living, which can be analysed through a Heideggerian reading of the novel. In this light, Walt's life can be divided into three periods regarding his acquaintance with Yehudi: living with his uncle before meeting Yehudi, living with Yehudi, and running an individual long life after Yehudi's death. Each period subscribes to one part, out of three, of Walt's developing character in a philosophical sense: his ignorance (or his innocence), his experience, and his maturity. Walt's life can symbolically stand for Dasein's situation in Heidegger's philosophy, including Dasein's inauthentic "situatedness" among "the they", Dasein's hearing the "voice of conscience" in the state of "anxiety" and Dasein's "resoluteness" in satisfying its life possibilities in the face of death. Understanding Auster's existential message is possible by analyzing the novel through such existential concepts in Heidegger's philosophy, which need to be elaborated later in the essay in discussing the novel. Interpreting $\mathrm{Mr}$ Vertigo in this light is new to the literature, although investigations into Auster's existentialism are common. 


\section{The Review of Literature}

Van der Vlies (1998) studied Auster's engagement with the possibilities of making sense of an individual's identity in the late-twentieth-century context. Focusing on Auster's selected novels, including Mr. Vertigo, Van der Vlies has explored the representation of identity in Auster's work in general terms. He concludes that Auster has sought to highlight the concept of "menschlikeit", which stands for "a standard of behaviour for persons not in an ideal, but in this imperfect, world, prescribing the assumption of ethical responsibility" (ibid., 60). This concept necessitates that Auster's protagonists accept their responsibilities in the world and come to recognise "a profoundly ethical conception of the possibilities and responsibilities of selfhood” (ibid., 156).

Alawneh (2013) has discussed “Auster's revisiting of existential nihilism" in In the Country of Last Things and Mr. Vertigo. She has tried to show, in the light of Gianni Vattimo's philosophical views on nihilism, how Auster's characters in these two novels adapt to nihilism via "active nihilism" or "embodying a positive attitude in a nihilistic world". She has also tried to show that characters "transform from a state of passive nihilism into a state of active nihilism through resorting to a form of art as a strategy of coping with hardships" (ibid., iv).

Álvarez $(2014 ; 2016)$ has also discussed the influence of Blanchot on Auster's certain novels, including $M r$ Vertigo. Álvarez believes that, following Blanchot's existential concerns, Auster's interest in Existentialism in writing postmodern fiction derives from Blanchot's influence, who in turn was influenced by Heidegger regarding the role of language in presenting reality.

It should be emphasised that Auster's existential concerns are not new for his present readers - Sartre and Blanchot have partly influenced him - but no specifically Heideggerian reading of $\mathrm{Mr}$ Vertigo, to highlight the existential undertones of the novel, has been undertaken. Auster has a couple of references to Heidegger in his nonfiction, when he talks about the poetry of Paul Celan in "The Poetry of Exile" (Auster 2005, 357), but he has never mentioned him as an inspiration. Notwithstanding this fact, his fiction is rich with Heideggerian existentialism when human possibilities and contingency become the main themes.

\section{Walt's Ignorance/Inauthenticity before Meeting Yehudi}

Leading a terrible life with Uncle Slim and his wife, Walt is "begging nickels on the streets of Saint Louis" at the age of nine until Master Yehudi finds and saves him (Auster 1994, 3). Walt's life in Slim's house has nothing individually valuable 
for him to declare his existence to the world. In Heideggerian terms, this state of Walt's life can be compared to Dasein's preliminary presence among "the they" in the world. "Dasein", Heidegger's term for human beings as they find themselves in a specific situation in the world, already lives with others or "the they" in the world. In other words, each human being is essentially "situated" in the world "in relation to others", meaning that human existence is simultaneously "being-forself, being-with-others, and being-in-the-world" (Michelman 2008, 2). This fact highlights the simultaneous existence of "bonds and limits" for each individual in his/her existence as well as his/her "possibility and opportunity" in any situation (Blackham 2002, 162). Concerning possibilities, each situation lacks a "desired, expected, intended or anticipated" possibility for the individual (Cox 2008, 29). And in so far as human beings are involved with others, mostly blindly in ignoring their life possibilities, they are leading an "inauthentic" life. "Dasein" thus initially finds itself in the state of "thrownness", that is, in a situation in which it essentially finds itself trapped among others and under their subjugating power (Heidegger 2001, 174). Under Slim and his wife, who represent "the they" in Mr Vertigo, Walt has in fact lost his individuality and life possibilities for a herd-like living, ignorant of the opportunities that can help him out of that limiting situation. Walt can escape from his uncle to change his life, but he is ignorant of this possibility. In other words, escaping from his uncle is not a null possibility. "Dasein", Heidegger $(2001,331)$ tells us, is "essentially null", that is, it is always open to other possibilities than the present ones, a fact that is concerned with Dasein's "being-free" for its possibilities. "Dasein" can, therefore, "call" itself to its range of possibilities from the standpoint of its "lostness" in "the they" (ibid., 333). Walt is, therefore, still capable of choosing other possibilities so that he can live authentically. His "thrownness", in a Heideggerian interpretation, is not absolute; as "Dasein" he can be other than his "thrownness" and moves beyond it. Walt's state of passivity or inauthenticity in living with Slim thus makes him a potent case for experimenting with human potentiality for being. Consequently, it makes sense to consider Yehudi's decision to train Walt as an existential upbringing. As Walt says, "Yehudi chose me because I was the smallest, the dirtiest, the most abject. 'You're no better than an animal,' he said, 'a piece of human nothingness'" (Auster 1994, 3), "that's where he started me out: in the barn with the animals" (ibid., 15). Walt's miserable life under his abusive uncle has not made any contribution to his existence in general since Slim has imposed on him the meanest life situation. This state of living stands, in an existential sense, for an individual's ignorance or "inauthenticity" among others, in so far as he/she is living without willingness in fulfilling the gifts of life.

Walt's inauthentic life as "thrown" in his uncle's realm of being is, however, a possibility of living among others, but it is the worst one that Walt could imagine 
if Yehudi did not appear. Yehudi thus symbolically stands for Walt's inherent willingness to fulfill the possibilities of his being. As Heidegger says, "As long as it is, Dasein always has understood itself and always will understand itself in terms of possibilities" (Heidegger 2001, 185). Yehudi is Walt's possibility of becoming more than what he is. At the end of the novel, Walt even becomes another Yehudi in trying to play his master's role in life.

\section{Placebo Effect and Walt's Experience of Being with Yehudi}

Master Yehudi is partly based on Auster's maternal grandfather who "turned himself into an accomplished amateur magician" and appeared in each of Auster's childhood birthdays, besides "touring the senior citisen clubs of New York" with the name of "the Great Zavello" (Auster 2005, 101). Moreover, Auster says in an interview that Yehudi's biography is "quite similar to Houdini's, who was also a Hungarian Jew who came from a family of rabbis", a man who bore "the contrast between...the mythical and the everyday...side by side in the same world", an issue that is part of Mr Vertigo and "establishes its tone" (as cited in Hutchisson 2013, 96).

Although Yehudi is initially introduced to the reader as Walt's savior, it is Mother Sioux who presents us with Yehudi's heroism later in the story. It was Yehudi who, on his way back to his farm, after rescuing the baby Aesop from cotton fields, saved the young Sioux from her abusive husband. Yehudi is thus portrayed as a man of God, as suggested by his name. "Yehudi" literally means a "Judean", "Jewish" or "Jew" in English (Baskin 2011, 666), and is derived from the Hebrew "Yehuda" or Judah, who was the fourth son of Jacob and the founder of the Kingdom of Judah. "Yehudah" literally means "thanksgiving" or "praise" and comes from a Hebrew root meaning "to thank" or "to praise". This meaning is reflected in Leah's, Judah's mother, remark at the time of Judah's birth, as it is recorded in Gen. 29:35: "This time I will praise the LORD" (Exell 1892, 583). Yehudi is not alien to the significance of his name; when he lets Walt enter his realm of being, the pupil must obey the master's rules of life. Observing Walt's racist attitude toward Aesop, for example, Yehudi deems that

All men are brothers, and in this family everyone gets treated with respect. That's the law. If you don't like it, lump it. The law is the law, and whoever goes against it is turned into a slug and wallows in the earth for the rest of his days. (Auster 1994, 13)

According to Auster, there is "a religious dimension" to Yehudi's Judaism since he "truly believes in these values", values which are "very Jewish", as in "The law is 
the law" (Auster and Siegumfeldt 2017, 185). "If, technically", Auster continues, "the Master does teach him [Walt] how to fly, he also teaches him how to become a human being. Tolerance and equality are the bedrock on which everything else is built" (ibid., 187).

In order to discipline Walt for an authentic state of being, Yehudi makes Walt pass through a series of hard labours. These labours are not only to purify Walt's soul but also to shape him according to his possibilities, that is, his potentialities as a human being. Yehudi has decided to train Walt into manhood and levitation, having challenged his former life. As such, Walt represents human nullity in his initial state of being - he was imprisoned like a shapeless piece of clay in Slim's rotten ground. Yehudi here reveals his role as the shaping power in Walt's formation/ creation to help the young boy be there in the world, knowing his possibilities of action. Moreover, Yehudi knows many things, including levitation, geology, weather, physics, and philosophy, which make him a distinguished mentor for the shapeless Walt. As Auster says in an interview, Yehudi is "interested in spiritual truths. Defying the laws of nature, as he proposes to do with Walt, puts him in a very precarious and interesting position with God, with the universe, with man" (as cited in Hutchisson 2013, 96). "He knew things I would never know", Walt tells us, "he heard things no one else could hear, and not a man in the world could match him" (Auster 1994, 116). Regarding one of the themes of the novel, "the creative process of creating or authoring a character" (Brown 2007, 109), it is Yehudi with his creative power who collects Walt's dusts from the ground and shapes them into a human being to wonder in a heaven of opportunities. This heaven is symbolically represented both by the farm as a microcosm where Walt is trained and America as a macrocosm throughout which he performs his shows. Still more, the very words with which Yehudi addresses Walt bear a biblical tone, as if God is talking to Adam in Eden: "I'm offering you the chance of a lifetime", Yehudi tells Walt, "but you only get that chance once" (Auster 1994, 4).

Heidegger $(2001,155)$ tells us that "Dasein" initially "finds" itself in "what it does, uses, expects, avoids" in the world. Moreover, in understanding itself, "Dasein" has to encounter others, or what Heidegger calls "Dasein-with". In other words, "Dasein" does not encounter others as mere objects; others are always observed in their involvements with the world. Their activities are "existential mode[s] of being" which point to their being in the world. Accordingly, Dasein's "beingwith", which is its presence in the world as an essential part of being a human, is in relation to "the occurrence of Others" or the presence of other people (ibid., 156). Such togetherness or caring for others has some "possible ways" of manifestation, including "Being for, against, or without one another, passing one another by, not 'mattering' to one another". These modes of being are mostly "indifferent" and 
characterise the "everyday, average being-with-one-another" for "Dasein" (ibid., 158). In other words, all people are present in the world in the face of each other. So "Dasein" does not live alone and its being is with others (ibid., 159). To be with others, or to be in the world "for the sake of Others" (ibid., 160), requires that "Dasein" understands Others. A part of Dasein's self-knowledge is rooted in "being-with" Others and understanding them (ibid., 161), because it is a mutual process of understanding between each two persons, each two groups of people, or a person and a group of people. When Others mutually come to this understanding, "a relationship-of-being from Dasein to Dasein" emerges and the result would be "a Projection" of oneself into Others' selves (ibid., 162). When we look at Yehudi's character, he gradually appears to have acquired the understanding that "Dasein" comes to possess during the course of an authentic life. In fact, Yehudi's character has been rendered in such a way that he has such understanding even before he is introduced to us, but it is through his encounters with Walt that the dimensions of his fully developed character gradually appear. Imagining the Dasein-figure is not possible without imagining it in the world and with others since it is only in that context that the possibilities of being human are fulfilled. One must know oneself in collaboration with others in the world for the good of all.

"Resoluteness" is what Heidegger calls "authentic being-one's-Self" which helps "Dasein" neither alienate itself from the world nor isolate itself as "a free-floating 'I'" away from others. "Resoluteness" makes Dasein understand that it is "beingalongside" others in the world. Moreover, Dasein's "resoluteness" as such makes it possible for "Dasein" to let others be in their "ownmost potentiality-for-being" as well. It is to say that "Dasein" is resolute when it lets Others be "resolute" as well. Subjugating Others in any mutual relationship in not included in the domain of being authentic. It means that once "Dasein" is "resolute", it can become the "conscience" of others by helping them become "resolute" as well. If this happens to all, everyone becomes "resolute" and thus through "authentically Beingtheir-Selves in resoluteness" all people can "authentically be with one another" (Heidegger 2001, 344). In Mr Vertigo, Yehudi, who is Jewish, acts likewise in so far as he helps a miserable Indian woman, a left-to-die black baby, and an abused (maybe Christian) orphan gradually acquire their self-knowledge as human beings of their human possibilities. Their authentically communal life is regardless of their religion, skin color, and social class.

"Irresoluteness" stands for "being-surrendered" to things which have been primarily imposed by Others on us, while "resoluteness" signifies "letting oneself be summoned out of one's lostness" in those preordained things. "Resoluteness" requires that all those who are already in the process of understanding their "irresoluteness", or ignorance over their possibilities, hear the "call of conscience" 
(Heidegger 2001, 345). Heidegger defines "conscience" as a silent voice within us, not the voice signifying any moral regret, which summons us to our "potentialityfor-being": it "calls us forth into the Situation" away from the prescription written for us by "the they" (ibid., 347). This call, however, is not heard by all people in their routine lives. Heidegger insists that it "reaches him who wants to be brought back" to himself (ibid., 316), who wants to bring himself into "taking-action" against selflessness (ibid., 341). In understanding "the call", "Dasein" finds itself in the "anxiety of conscience", that is, in a state of alienation from the world by understanding that there is always the possibility of being other than what one is (ibid., 342). Just like someone who calls us back to our consciousness when we are lost in some diverting activity, the "voice of conscience" calls us back to our selfhood. Walt's lostness in his life with Slim represents this diversion into selflessness, and his situation does not let him hear his voice of conscience. It is through Yehudi that he understands that becoming a better person is not impossible and he thus finally succumbs to the voice of his conscience, which symbolically turns out to be Yehudi. Yehudi, being resolute himself, not only has heard his own voice of conscience to lead life authentically but also has become the conscience of others to call them into better lives. As Dahlstrom $(2013,184)$ notes, "being-withone-another authentically - even being the conscience of others-springs from resoluteness", giving "Dasein" the insight to disclose and choose the possibilities at hand. To bring Walt to this understanding, Yehudi initially addresses him with sarcastic remarks and insults to remind him of his former worthlessness. "He might not have thrashed me the way Slim did", Walt says, "but the master's words had power, and they hurt" (Auster 1994, 15)-Yehudi even once declares that his behaviour is meant to "break" Walt's spirit (ibid., 17). In order to renew his life, Walt has to go through what Yehudi wants him to do. It is a question of either/or for Walt, a pure binary opposition between authentic life and inauthentic life, in existential terms. For Walt this renewal might initially resemble an imposed way of living, just like his life with Slim, while Yehudi symbolically represents Walt's conscience which calls him guilty of that inauthentic life and wants him to rebuild himself. On the way to Yehudi's farm, Walt has the chance to flee from Yehudi but he chooses otherwise: "in that choice hung the entire story of my life. I went back to where the master was waiting because he'd promised to turn me into a millionaire" (Auster 1994, 8-9). Walt is here tempted to follow Yehudi for the sake of a better life, but he tries to escape once again when he faces the harsh conditions of the farm. However, passing through each labour, as if satisfying the voice of his conscience, Walt recognises what he is capable of doing. Until he hears the truth of Yehudi's voice, Walt makes several attempts to escape but each time Yehudi appears before him. As Walt puts it, "the bastard was inside my head" from whom "not even my innermost thoughts could be hidden" (ibid., 26), a fact which finally makes Walt stay in the farm and pursue his training. It seems that Yehudi, as Walt's 
conscience, insists on calling him into action by appearing whenever Walt tries to escape from himself. He gradually recognises Yehudi's conscience-like presence. Walt associates his failures to escape with "an invisible force" which robbed him of his strength and will. It seemed Yehudi had turned him to "a puppet" (ibid., 27).

It is true that Walt succumbs to Yehudi's rules, but this selfless commitment is directed toward a transcendental objective which in fact helps him fulfill the possibilities of his being. Walt is a puppet under Yehudi just like he was under Slim, but the former state is authentic while the latter was inauthentic. Walt is the puppet of his conscience under Yehudi, who calls him to the possibilities of being a human. This state of being for Walt coincides with his last escape, which ends up in Mrs. Witherspoon's house where Yehudi is present as well. Walt becomes terribly ill that night, having wandered several hours in cold weather. Yehudi interprets the illness as the "Ache of Being" which he claims "was bound to strike" Walt sooner or later, so that Walt could face some miserable state and become more ready for what was to come (Auster 1994, 32). After his recovery, Walt finally recognises the nature of Yehudi's intention for the development of his character, symbolically hearing the voice of his conscience: "I'd learned that escape was pointless", Walt says, "and now that I was stuck there whether I liked it or not, I decided to make the most of what I'd been given" (Auster 1994, 34). Walt thus gradually develops intimate relations not only with Yehudi but also with his companions. Walt was initially "a racist" against Aesop and "a misogynist" against Mother Sioux, but "all that changes in the hands of Master Yehudi" (Auster and Siegumfeldt 2017, 181). "You're living in the same house with a Jew, a black man, and an Indian", Yehudi tells Walt, "and the sooner you accept the facts, the happier your life is going to be" (Auster 1994, 22). Walt's later development of the feeling that he is looking at himself by looking at his new family reflects the fact that he is now more conscious of his position in the universe among others. Being among those who have become resolute in Yehudi's hands in fact reminds him to keep up with an authentic way of life. Yehudi in particular, Walt says, "marked me in ways that altered who I was, that changed the course and substance of my life" (ibid., 36-37). Thereafter, Walt makes his best "to keep up" with Yehudi (ibid., 46), who believes, "No matter how dark our troubles might be, I'll always find a way to pull us through" (ibid., 52).

There are altogether 33 breath-taking labours that Walt must pass in order to master levitation. It is through Mother Sioux and Aesop and getting familiar with Sir Walter Raleigh through Aesop that Walt finds consolation during his labours. Sioux and Aesop do as Yehudi does in treating Walt to master his situation and obtain resoluteness: "Aesop and Mother Sioux stuck by me as if I were their flesh and blood", Walt says (Auster 1994, 43). Their favors contribute to the authentic life that Yehudi has depicted for them. Raleigh, who significantly bears Walter as 
his first name, also inspires Walt in his own style: "I carried Sir Walter inside me as a second self", Walt says, "an invisible brother to stand with me through thick and thin" (ibid., 44). The life stories that Aesop tells about Raleigh specifically encourage Walt to keep up with his quest. Walt finds his own image in Raleigh, as if he is Raleigh's doppelgänger, with his name Walter Rawley alluding to Walter Raleigh as "an explorer" in his young age and an "elderly man who writes" (Barone $1995,21)$. It is also surprising that Raleigh's eldest son was called Walter - he was killed during Raleigh's "disastrous expedition” to Guinea (Drabble 2000, 835). Just like Yehudi and his Spinoza, one of whose books Yehudi always has with him, Walt finds consolation and inspiration in Raleigh. As Auster elaborates on Raleigh's final hours in his thirteen-year imprisonment in the Tower of London, just before his beheading, Raleigh was open to all possibilities in the face of his death: "He can reduce himself to a stone, or he can write the history of the world. Where no possibility exists, everything becomes possible again". Raleigh for Auster radiates "an art ... of living;" he is a man deprived of life while still continuing "to exist" (Auster 2005, 305). For Raleigh, Auster continues, "At each moment there is the possibility of what is not" until death, so that "he will throw himself into life" in the face of the truth that we ultimately die. "For death is a very wall, and beyond this wall no one can pass". Raleigh learned that "he is nothing more than a body, and... a mind", that "he is nothing". He knew that "at each moment he is the captive of others", but "his thoughts belong to him". Raleigh "lives to the fullest that his confines will permit" (ibid., 306). It is implied that Raleigh's life inspires Walt to withstand the difficulties of his labours. These events are "voyages of discovery - self-discovery", following Raleigh's style of exploring the world and his heroism (Brown 2007, 108). Through his labours, Walt is flogged, thrown from a horse, "lashed to the roof of the barn for two days without food or water", "dunked repeatedly for six straight hours in a tub full of vinegar" and "struck by lightning". He has to stand naked with a honey-rubbed body before a thousand flies and wasps, sit in a circle of fire for one whole night, drink "cow piss" and eat "horseshit", cut off the upper joint of his pinky, and dangle "for three days and three nights in a cocoon of ropes from the rafters in the attic". Walt goes through all these tortures because Yehudi wants him to do so, following "his commands with blind obedience" since Yehudi had promised to make him fly (Auster 1994, 42), since his conscience needs to leave its imprints on his soul. The common element among all these labours, as Deshmukh says, "is the fact that they are all corporeal", the whole program being "an experience of physical suffering" (Deshmukh 2014, 135). Accompanied by Raleigh at heart, Walt gradually develops his character after each labour. Buried alive, as one of the hardest labours, Walt feels that the weight of dirt on top and "the panic of deathlike immobility" in the grave are nothing compared to the anxiety one faces when unburied; "From then on, everything that happens to you on the surface is connected to those hours you spent underground.... 
Death lives inside you, eating away at your innocence and your hope" (Auster 1994, 41-42). Walt's symbolic death in a grave resembles Raleigh's imprisonment in the Tower in so far as their speculations over death or their probable freedom are concerned. It was Raleigh's conditioned freedom to serve the King on a new expedition than his execution that limited his life. Walt likewise fears his life on earth after exhumation. However, Walt's burial and resurrection make him ready for a new life, no former vanity involved: "That was how my initiation began... and the farther I was pushed, the less pride I felt in my accomplishments" (ibid.). Moreover, the resurrection metaphor is incorporated into Yehudi's transcendental attitude toward Walt's training. The novel is "articulated around Walt's learning to transcend his body", or to "fly", with Yehudi's help. "This transcendence is all the more striking, as its starting point is abjection" (Deshmukh 2014, 226). It then makes sense why Yehudi insists on crashing Walt's vanity before turning him into a man of certain skills.

Walt's middle name, Claireborne, can be read as "Cl/airborne" to emphasise "the ungrounded episode in his story" (Brown 2007, 108). Walt is reborn when he is in the air as "a person who did not exist except when he was in the air" (Auster 1994, 137). His first levitating experience highlights this new beginning for him; his "struggle" is not only "to master the skill" but also "to absorb its gruesome and shattering implications" in so far as it has marked him "with a special destiny" to set apart from others for the rest of his life (ibid., 62). After failing "a thousand times", Walt finally succeeds to go "up and out at the same time" (ibid., 80), and he keeps on "working with confidence" (ibid., 81). Dedicating himself to his skill thereafter, Walt feels that something has shifted inside him: "The ground was an illusion", Walt holds, "a no-man's-land mined with traps and shadows, and everything that happened down there was false. Only the air was real now", away from his "old pleasures and habits" (ibid., 137). Walt even develops walking on water, once more highlighting the transcendental aspect of his skill: "I was walking on water with the same skill as Jesus himself" (ibid., 86). By transcending the earth and the world of "the they", in Heideggerian terms, Walt acquires the knowledge of his "potentiality-for-Being" and moves beyond the trappings of his inauthentic life. His understanding of his possibilities against "the they" and their limiting situation is so strange in others' eyes that they suspect his truthfulness: "They believed the world was set up in a certain way, and there was no place in it for a person of my talents" (Auster 1994, 177). Lostness in the world and permanent inauthenticity among "the they" have blinded most people to their individual skills. Accordingly, levitation simultaneously "separates Walt from the world" and "separates his mind from his body" (Deshmukh 2014, 230), distancing him from the human world and the laws of the earth, respectively. In symbolic terms, Walt's body stands for his pre-established presence in the world with others since "Dasein", as Heidegger 
(2001, 121) puts it, "has always submitted itself already to a 'world' which it encounters". "Absorption" in "the they" and the world highlights "a fleeing of Dasein" in projecting itself as "an authentic potentiality-for-Being-its-Self" (ibid., 229). It can be argued then that Walt's momentary excursion into the air, that is, his transcendence after hearing the voice of his conscience to satisfy his possibilities of action, is merely an episode in the course of his inauthentic being with others in the world. We are born among "the they", and we grow up mostly being ignorant of our possibilities unless we hear the voice within to take authentic action for the sake of our "potentiality-for-Being" (Heidegger 2001, 174). Meanwhile, falling back to the ground, Walt symbolically comes back to the inauthentic word of "the they". When he is on the earth, Walt is in fact back to his state of "thrownness" among others, which is the background of Dasein's continuous attempts at living authentically. The fact that authentic living is not an end to be achieved but a process to be consciously pursued implies that we are always subjected to inauthenticity and that its presence never dies out in our lives. Heidegger $(2001,185)$ argues that "Dasein" is always to understand itself "in terms of possibilities", since its "potentiality-for-Being" depends "existentially" on "understanding". "Dasein" is, therefore, "Being-possible" or "what it can be" in relation to itself, the others, and the world (ibid., 183).

As "Being-possible", "Dasein" develops "sight" through "understanding" to find itself in its possibilities, acquiring the "knowledge of the Self" to know that it is "not yet" (ibid., 186). Regarding my present state of being, for example, I am not my future yet. In so far as I know that I have future possibilities and that I can escape any limiting situation for other possibilities, I am living authentically. Thus the knowledge over my possibilities of being is the placebo effect of my being since I know that they are just a range of possibilities which may happen or not.

A placebo is a medicine or a procedure which has "positive effects as a result of a patient's perception that it is beneficial rather than as a result of a causative ingredient". The term itself originates from the vespers of the Office of the Dead in the Roman Catholic Church as the first word of the first antiphon, taken from Psalm 114:9 of the Vulgate: Placēbō Dominō in regiōne vīvōrum, "I shall please the Lord in the land of the living". A placebo has no therapeutic effect on patients and is merely prescribed to them to psychologically deceive them into imagining that it is an active therapy. The improvement in the physiological condition of the patient caused by such medication, which is in fact because of the "patient's expectations concerning the treatment rather than from the treatment itself", is called the "placebo effect". Basically defined as a medication mostly used to please than heal the patient, placebos have been considered therapeutically effective by some and not to be clinically functional by others (Gensini et al. 2005). One wonders what 
the patients' reactions would be if they come to know what they have been given as cure. This is what happens to Walt in mastering levitation for the first time:

When I finally got off the ground...I did it by myself..., and it came after a long siege of sobbing and despair, when...I was no longer conscious of who I was.... In that case, the physical ordeals he [Yehudi] put me through were no more than a sham, a diversion to trick me into thinking I was getting somewhere - when in fact I was never anywhere... what if his way wasn't the only way? (Auster 1994, 277-278)

Walt recognises that Yehudi's directions were tricks, just like placebos for treatment, but he still wonders whether they were the only effective tools to help him levitate, just like placebo effects the functionality of which are psychic than therapeutic. Yehudi acts as a placebo whose "placebo effect" encourages Walt to pursue his dream to fulfill his possibilities as far as possible, although he knows that no final fulfillment is possible. As Auster says, Yehudi believes that:

he's disciplining him [Walt] to withstand pain and fear. He's teaching him to become a real artist, to concentrate under adverse conditions.... And then there's what I would call the placebo effect. If he can convince Walt to believe in the program, then maybe something will happen. He even cuts off a part of Walt's finger, convincing the poor boy that the little joint has been weighing down his body. Then it works! Walt floats across the lake. (Auster and Siegumfeldt 2017, 189)

Yehudi tells Walt, after cutting one of his pinky joints, "[that pinky joint] used to belong to you. For the first ten years of your life, it was part of who you were" (Auster 1994, 47). Yehudi's butchery here is to separate Walt "from his worldly or corporeal past", and the disembodied joint symbolises that past (Brown 2007, 107). Even when Yehudi makes a necklace out of the joint and gives it to Walt as a prise for his first levitation, he once more encourages Walt to throw it away since he cannot move higher in the air. Walt denounces Yehudi's claim by stating that "It's my lucky charm, and I can't do nothing without it". Yehudi has to denounce this claim by stating that "the first time you got yourself off the ground, it was slung around my neck" (Auster 1994, 87). He thus persuades Walt once more to leave a part of himself behind to attain "the full magnitude" of his skill (ibid., 88). The placebo is thus here nothing but one's will, one's choices, while in essence every choice out of one's will is one among many choices. In other words, Walt could choose not to follow Yehudi's orders and follow his painful former life.

Yehudi's play with the concept of the "placebo effect" derives from his reading "over and over again" a book "of all things" by Spinoza (Auster 1994, 123). As 
Auster says, "Spinoza is the only Jew in the pantheon of Western philosophers. He reflects on ways of thinking about the power of God in nature. That's the spiritual side of Master Yehudi" (Auster and Siegumfeldt 2017, 184). Yehudi's interest in Spinoza is further colorful when we consider Spinoza's belief that our desires in life originate from illusions of which we do not have the faintest idea:

Men believe that they are free, precisely because they are conscious of their volitions and desires; yet concerning the causes that have determined them to desire and will, they have not the faintest idea, because they are ignorant of them. (Spinoza 1992, 57)

We think that we are free, Spinoza thus says. And it is this illusion, the illusion of being free, that deceives us throughout life since in essence we are under certain conditions that could be otherwise and shape our lives differently. Our illusions are the placebos that veil truth and just control us even though we think that we are free. As Jopling interprets Spinoza, humans' vulnerability to "illusions and deceptions" is a widespread theme throughout Spinoza's works, and even throughout the works of such existentialists as Nietzsche and Sartre $(2008,23)$. One may also add Heidegger and his emphasis on Dasein's exposure to the prescriptions of "the they", in so far as "the they" delude "Dasein" away from its "resoluteness". According to Jopling $(2008,23)$ and his philosophical interpretation of the "placebo effect",

Mystifying interpretations of human experience serve the function of interpreting otherwise unintelligible sufferings, unexplained natural forces, and puzzling behaviors, thereby making them more tolerable than they would otherwise be, and supplying for them a schema of putative remedies or coherent responses.

Having already fulfilled his role as Walt's conscience and trying to help him pass through the difficulties of his art by playing the role of a placebo for him, Yehudi once more highlights the effects of his psychic therapy for Walt when the boy develops severe headaches following a fall in one of his performances. These headaches lead Yehudi to change Walt's name to "Mr Vertigo", with the occasional alternatives "Mr Dizzy-in-the-Head" and "Mr Fear-of-Heights" to encourage him not to lose hope (ibid., 186). However, Yehudi recounts what happened to two former levitators when they developed headaches while and after levitating to make it clear for Walt what is before him in this practice - they had to go through castration; one of them succeeded and the other failed and committed suicide (ibid., 191). Since the operation is not guaranteed, Walt chooses to end his glorious days as "Walt the Wonder Boy". Yehudi accepts their fate right on the spot: "We might be out of the levitation business", he tells Walt, "but that doesn't mean we've closed up shop" (ibid., 195). Not losing hope in the face of failure is 
Yehudi's reality principle, and as such, he is the one who constantly imposes hope on Walt, just like placebos that only make patients hopeful, without possessing guaranteed therapeutic effects.

Metaphorically enough, by descending onto the ground, Walt flees from transcendence and takes a refuge in the world of others. "Dasein", in Heidegger's words, "flee[s] into the 'at-home' of publicness", that is, "Dasein" as "thrown" sees the "uncanny" or hears the call of conscience but escapes from it. The fact is that "uncanniness", or the call to resoluteness, is always pursuing "Dasein" and threatens its "everyday lostness" in "the they;" "uncanniness" is a force which tries to pull us away from everydayness towards authenticity (Heidegger 2001, 234). Whenever "Dasein" happens to "fall", it is "anxiety" that saves it from immersion in "the they" and individualises it (ibid., 233). As it was argued above, it is only within the state of anxiety that "Dasein" hears the call and understands that it is free to choose other possibilities. The main question here is whether Walt is enchanted, duped or influenced by Yehudi as the one reminding him of that anxiety. Walt's vulnerability to illusion and deception by Yehudi, when he was nine and led a bad life with his uncle, drove him away from his own will to master his condition on his own. In other words, Yehudi was like a placebo for him that he took on the spot. But he was not able to master any better fate in that pathetic situation. That is why Yehudi, in a placebo-effect-like manner, helps Walt reunite with himself by calling him to his authentic self. Yehudi is thus Walt's voice of conscience, a voice which Walt could not hear since he was blocked from understanding his life possibilities.

One's conscience is a good friend in one's company. According to Mulhall (2003, 278), the existence of this friend can dismantle "Dasein's lostness in the theyself" and create in those individuals seeking authenticity the conditions for hearing the "call". Such a friend would somehow speak "from outside or beyond us" and tries to help us "recover our capacity for selfhood, our autonomy". It attempts to recall us to "our capacity for individuality" by having us listen to its "specific demands". As such, the "call" would function as "an external representative of an aspect of ourselves", a "repressed" aspect of ourselves which reminds us of "our ownmost potential for authenticity". Yehudi's name, implying someone praising God, and his placebo-like character, implying someone pleasing God in its Latin definition, highlight the transcendental aspect of his being which symbolically acts as Walt's conscience. When Walt's last escape fails, Yehudi warns him that "Now you know, wherever you turn, that's where I'm going to be. However far you run, I'll always be waiting for you at the other end. Master Yehudi is everywhere, Walt, and it isn't possible to escape him" (Auster 1994, 30-31). Moreover, it is Yehudi himself who constantly encourages Walt to tolerate his labours: "United we stand, divided we fall. You for me and me for you, and where we stop nobody knows" 
(ibid., 48). "Whatever you are", Yehudi tells Walt elsewhere, "it's because of me", and that "it works both ways. Whatever I am, it's because of you" (ibid., 208). Walt later reflects that "I had learned that everything I was flowed directly from him [Yehudi]. He had made me in his own image" (ibid., 53). Conscience is not something which calls "Dasein" in a single moment and then leaves it for good. By showing Dasein's true selfhood to it in every moment of its life, conscience in fact directs "Dasein" to an authentic way of living until death.

According to Auster, "why risk your life for something that is at bottom utterly useless?" (Auster and Coetzee 2014, 130). In other words, why does Walt endanger his health for some useless skill? Auster answers that "one could arrive at a better understanding of the aesthetic impulse in human beings ... when we do things for the pure pleasure of doing them", for their "uselessness" (ibid., 131). Such uselessness can, however, be meaningful. Levitation acts as a particularly existential metaphor in $\mathrm{Mr}$ Vertigo, although it is a useless art in essence. Auster seems to announce his existential message through "loft and locomotion" (Auster 1994, 69), which is flying "not like a bird" but "like a god" (ibid., 70). However, "trial and error" is Yehudi's catchphrase to motivate Walt in loft and locomotion (ibid., 71). Several hard labours should be passed to attain some internal balance between the body and the mind, and then maintaining that balance would become the sole object of one's life. After "the physical stages", Walt holds, "what stood before me now were the stages of mental struggle, the showdown between myself and myself" (ibid., 49). "Dasein" is "resolute" in establishing a mental balance between the demands of the call of conscience and worldliness. Inauthentic excursions into the world of "the they" for the individual who tries to be authentic is an inevitable part of life - one cannot be always authentic. Likewise, remaining in the state of anxiety, in which one recognises one's possibilities of action, is not realistically possible. An anxiety-stricken individual is rather mad and confused all the time and cannot decide what to do. Walt, through Yehudi, hears his conscience and recognises that possibilities do exist. In this regard, human being's essential art is to keep the balance between the demands of the soul and those of the body, just like what Philippe Petit and his high-wire walking art showed humankind. Philippe Petit, to whom Walt and his levitation allude, proved that satisfying one's possibilities in life is a "story of a quest, an exemplary tale of one man's search for perfection" (Auster 2005, 441). Petit, in Auster's perspective, practiced high-wire walking merely "to dazzle the world with what he could do". Petit's motives did not follow those of other artists; he developed "an ambition and an arrogance fit to the measure of the sky, ... placing on himself the most stringent internal demands". Petit wanted "to do what he was capable of doing" (ibid., 439), while he "had assumed full responsibility for his own life". His art was not "an art of death, but an art of life - and life lived to the very extreme of life" (ibid., 443). In Petit's own 
words, which summarises his life and art in one very short maxim, "I learned how to control my life" (as cited in Auster, Prose 440). By alluding to Petit, Auster's Walt shows us what a human being can do in establishing a unique balance between the body and the mind up.

In order to keep the balance between his mind and body, Walt has to stop levitating - his severe headaches are not going to heal if he goes on with levitating. However, on Yehudi's demand, he hopes for other oppurtunities, other possibilities of being. But his dreams turn into nightmare when Walt is kidnapped by his uncle. With the loss of his power, Walt's state of inauthenticity once more strikes him. This part of the novel highlights the fact that we are never free from the dangers of inauthentic life since it is in the middle of that life that we should recognise our possibilities. Walt finds the opportunity to escape from his uncle, from the passive state of living under his rule, and reunite with Yehudi. The reunion is blessed when they spend some time on vacation in Cape Cod both under similar false names, "Timothy Buck" for Yehudi and "Timothy Buck II" for Walt, to protect them from the press (Auster 1994, 160), which shows how they have come close to be one with each other. However, after the vacation, Yehudi is killed by Slim and his men on the road to New York. Moments before the misery befalls them, Walt thinks that Yehudi was "likely pondering questions about life and death", questions like "Why am I here? Where am I going? What happens to me after I've drawn my last breath?" (ibid., 189). Walt talks about these questions as if they are "a language of what ifs and what thens" (ibid., 200), or what life is in the face of contingent death. Bleeding to death, since a bullet hit him in his back, and being fully aware that his death is now better than his life with a belly cancer, Yehudi ends his life by his revolver. Commenting on his upcoming death, Yehudi holds that "I'm talking about the cancer in my belly. ... I don't have more than six months to live. Even if I could get out of here, I'm done for anyway. So why not take matters into our own hands?" (ibid., 210). Death, in Heideggerian existentialism, is the ultimate possibility that does happen to all, whether we commit suicide or not, unlike all the other possibilities that may or may not happen. Consequently, the only way to make death subjective and to control it is through suicide. As Deshmukh believes, here Auster emphasises "the paradox of the suicide:" suicide is the sole way of "preventing one's body from becoming the locus of unpredictable events", so that the only way to control one's body is "to annihilate" it (2014, 217). In Auster's words, "If there is such a thing as an art of living, then the man who lives life as an art will have a sense of his own beginning and his own end" $(2005,308)$. Throughout the novel, Yehudi is thinking about death, and thus his decision for suicide is not sudden. Living authentically in the face of his deadly cancer, Yehudi truthfully manifests "an art of living" and deems it right to teach it to Walt as the 
voice of his conscience. Even by his death Yehudi teaches Walt to try his best to fulfill the potentialities of his being in the face of death. In Walt's view,

Yehudi was the last of a breed, .... a man who felt perfectly at home in the jungle. He might not have been the king, but he understood its laws better than anyone else.... Never say die. He didn't just live by that motto, he was the man who invented it. (Auster 1994, 196)

"If the years have taught me anything", Yehudi once tells Walt, "it's that anything can happen" (Auster 1994, 117). The opportunities of self-empowerment or "potentiality-for-Being" with which Yehudi provides Walt, however, are merely placebos. They are gone when Yehudi is gone-the placebo effect is gone when there is no placebo anymore. Walt initially understands it when he levitates for the first time without Yehudi directly involved. Walt, representing "Dasein" not only in its initial but also its constant state of being, is "a piece of human nothingness", as Yehudi called him (Auster 1994, 3). Dasein is "nullity", as Heidegger puts it; it is the null basis of all the possibilities of action in life until death. Do nothing and you are a beggar for Slim, "the they". Do nothing and you are a clod of shapeless clay. That is why after Yehudi's death, which represents the silence of Walt's call of conscience to authentic self-hood, Walt passes through a state of aimlessness, just as he used to live with Slim. We can say that living before death can be hopeful if we consider the fact that there are always opportunities for us to be what we are not, although we know that no ultimate satisfaction is ever obtained. That hopefulness is like taking placebos, which function as psychic deceptions than real therapeutic cures for patients. Living authentically, even in the face of death, is to recognise our possibilities in a world which constantly drives us into its melting pot or the inauthentic worldliness of the "the they". Our life possibilities are placebos; once placebos are over, their effects are neutralised and ignorance follows, until death terminates our lives and our possibilities altogether. However, until death, it is our call of conscience that plays the role of that placebo to encourage us to do more and more, as in Yehudi's relationship with Walt.

\section{Walt's Maturity/“Resoluteness” after Yehudi's Death}

Walt begins still another life after Yehudi's death, this time without any placebo and its effects since he buries Yehudi and his Spinoza's book, newspaper headlines of his own success, and his cut finger joint, all reminiscent of his authentic life with Yehudi. He led a life, authentic as it was with consciousness of his possibilities, under Yehudi's "placebo effect". Having understood his position in the world more clearly now, Walt is on his own for the rest of his life. Once escaping the voice of his conscience, which was manifested in Yehudi's being, Walt finally chooses 
to hear the call himself and internalise it, instead of being reminded of the call by someone else. Walt finally learns to run his life authentically: "As long as I didn't dwell on the old days", Walt says, "I could deceive myself into thinking I had a future. It hurt too much to look back, so I kept my eyes fixed in front of me" (Auster 1994, 228). As the "Mr Vertigo" of the title of the book, Walt is always developing or changing on the path of life possibilities to satisfy his vertiginous being, that is, to satisfy his life possibilities while being conscious of them in a state of constant anxiety.

Up until finding Slim and taking his revenge, Walt lives a vagrant's life, wandering all over America to locate his uncle, living "from hand to mouth" to keep himself going (Auster 1994, 215). After killing Slim, Walt takes his job and works for Bingo, Slim's employer, as the only chance to survive: "When a man has only one chance", Walt says, "he's going to take it" (ibid., 221). Bingo somehow becomes another "mentor" for Walt, who takes him "under his wing" and changes his life again. Now more conscious of life opportunities, Walt swallows his pride and does what he is told to (ibid., 225-226). Contrary to his initial resistance to Yehudi, Walt obeys Bingo from the very beginning, knowing what the authentic choice is according to the situation. He thus begins his job as a gofer for Bingo but ends up as the owner of a nightclub, "Mr Vertigo's" (ibid., 240), which becomes wellknown in the region.

One of the regular customers in Mr Vertigo's is Dizzy Dean, "a real baseball player", whose story in the novel is both "based on fact" and "about Walt's failure" (Auster and Siegumfeldt 2017, 183). Dizzy, once a baseball star, is now experiencing his downfall at the end of his career. As Walt expresses his feelings for Dizzy, his "benighted soulmate and alter ego" (Auster 1994, 250), "Dizzy's ups and downs began to affect me in a far too personal way" (ibid., 245). Dizzy reminds Walt of his own failures; he finds in Dizzy his own image when he was in trouble before being saved by Yehudi. The similarities that exist between them link them together in a strange way: Dizzy played for Saint Louis where Walt comes from, and their nicknames are "so similar" - as Yehudi used to call Walt "Mr. Dizzy-in-the-Head" after he developed headaches (ibid., 186). Finally, as Walt says, "a moment came when I couldn't tell the difference between us anymore. His triumphs were my triumphs, and when . . . his career fell apart, his disgrace was my disgrace" (ibid., 252-253). Walt thus decides to help Dizzy as his "duty to persuade Dizzy Dean that he didn't want to live anymore", to save him "by talking him into his own murder". Walt sees himself as Dizzy's conscience, just as Yehudi played the role of Walt's conscience, and he cannot "stand to live through it again;" Dizzy has to die "for his own good". Dizzy's death is "not only for his sake", Walt says, "but 
for my sake as well" (ibid., 253). Walt invites Dizzy to his office to kill him and tells him that

I've been where you are, I was the best at what I did, ...something happened, and I couldn't go on. But I didn't hang around and make people feel sorry for me, ... I went on and made another life.... But you just don't get it. (ibid., 255)

Walt's tone and diction echo Yehudi's when the master found the pupil and verbally attacked him to make him realise that he lives inauthenticity. In fact, Yehudi, as "Dasein", played a significant role to make Walt conscious of his "potentialityfor-being", in Heideggerian terms. As it was argued, not everyone hears his/ her conscience but the resolute one. Having heard his/her voice of conscience, the resolute person can become others' conscience as well. However, Walt's prescription for someone like Dizzy who does not crave for any authentic life is nothing but death. Death for Walt is the ultimate possibility when there is no other choice, and Dizzy has now reached that stage although he is still alive. "Let me help you, Diz", Walt thus tells Dizzy, "Death isn't so terrible. Everybody has to die sometime, ... you'll see that now is better than later. If you give me the chance, ...I can give you back your dignity" (ibid., 256). Walt is in fact iterating what Yehudi told him before shooting himself: "it's the best solution for both of us," so "why not take matters into our own hands?" (ibid., 210); "Death isn't so terrible, Walt. When a man comes to the end of the line, it's the only thing he really wants" (ibid., 211). "Let me kill you", thus Walt recommends Dizzy, "You'll be great again forever" (ibid., 256). However, Walt's fails to kill Dizzy and loses his job when Dizzy files a lawsuit against him.

The loss of Mr Vertigo's puts Walt into turmoil once more: "I was nobody special now. Just my old ordinary self again", he tells himself (Auster 1994, 259). Walt "experiences an existential descent into the void" after this incident (Martin 2008, 25); he sees his life "messed up and blown" but accepts the responsibility for his "downfall" and keeps on living in the face of helplessness. "I was all the way at the top when I stumbled", Walt says, "But no regrets. I had a good dance for my money" (Auster 1994, 241). He then attends World War II, instead of imprisonment for attempting to kill Dizzy, returns back to America in 1945, pursues several professions, marries twice, becomes alcoholic after his second wife's death, is rehabilitated in a clinic, and is luckily, on his way to his new job, welcomed by the old Mrs. Witherspoon when he stops by her house in Wichita to refresh old memories. It is now 1974 and Mrs. Witherspoon is managing the laundry in Wichita. Billy, her old lover-partner, is now retired and she wants Walt to take his position. When Billy dies, Walt also replaces him as her lover. Witherspoon dies 
at 90-91 when Walt is 76 . Financially secure in old age, Walt begins to write his autobiography, Mr Vertigo, to be published after his death.

Walt finally seems to have reunited with his conscience at the end of the novel. Having become another Master Yehudi by reflecting Yehudi's image in his own being, Walt decides to train his servant's eight-year-old son, Yusef, just in the same manner that Yehudi trained him:
I... see myself in him [Yusef] when I was that age, ... Watching Yusef, I now know what the master saw in me, and I know what he meant when he told me I had the gift. This boy has the gift, too. If I could...turn him into the next Wonder Boy. ...that would be something to live for... (Auster 1994, 276-277)

Walt, manifesting Heidegger's "Dasein", has become not only his own conscience but also the conscience of others to decide for them, following his mentor who did the same thing to him. Walt's role as others' conscience, when he considers their lives inauthentic, consists of killing Slim, trying to persuade Dizzy into his death, and planning to act as Yusef's godfather in Yehudi's style. Iterating Yehudi as a creator of an authentic life by destroying a former inauthentic one, Walt manifests Yehudi's being as both a destroyer of inauthentic life and a creator of authentic life. Particularly regarding Walt's worldview later in life, as Auster says, "As an old man, Walt, the narrator, believes that flying is connected to the desire for transcendence in all of us, the desire to do something extraordinary, to make something beautiful" (Auster and Siegumfeldt 2017, 180). Walt's journey in life is in fact the process of "literal rise and fall" and "his passage from innocence to experience" in this world (Varvogli 2001, 159), as it befalls all of us. Auster's novel thereby explores "the individual's existential descent into the abyss and subsequent quest of discovery" (Martin 2008, 21). Auster's question in the novel is "what constitutes a definitive truth, the significance of random contingent happenings," in other words, Walt's existence is "determined by his reaction to life-changing events" (Martin 2008, 27). "I don't believe it takes any special talent for a person to lift himself off the ground and hover in the air. We all have it in us... You must learn to stop being yourself", Walt tells us at the end of the novel, "let yourself evaporate. And then, little by little, you lift yourself off the ground" (Auster 1994, 278). His way of living, being Yehudi's disciple, is in fact an artistic life before death:

As long as I could imagine the thing I wanted, ... it would be available to me for the performance. ... I was evolving into an artist, a true creator who performed as much for his own sake as for the sake of others. It was the unpredictability that excited me, ... You have to keep testing yourself, pushing your talent as hard as you can. (Auster 1994, 131) 


\section{Conclusion}

Mr Vertigo is a novel about human potency in the face of failure and death. Auster's world in this novel begins with human nothingness and ends in human salvation, although not in the traditional sense. Walter's development of character delineates a process of transcendence from nullity, or ignorance of one's possibilities, to the manifestation of the Heideggerian "potentiality-for-Being", or the understanding that one is always capable of doing more than what he is. In other words, we can transcend our present state of being by embracing our potentiality for transcendence under certain conditions. The requirements for such change are to be alert to the voice of our selfhood, the voice of our conscience in Heideggerian terms. This voice calls us to take authentic action in every moment of our lives until death, which is the last event recapitulating life possibilities. Playing our human roles inauthentically in life by ignoring our possibilities objectifies our souls and deprives us of our very essence.

Walt embraces an existential journey towards the satisfaction of his possibilities of being a human through a mentor who symbolically stands for his voice of conscience. As "Dasein", Master Yehudi is a resolute person who has not only mastered his life possibilities, even his fate by committing suicide, but also has tried his best in life to encourage others to follow his style. Inheriting Yehudi's legacy, Walt acts likewise not only to lead his life authentically but also to help others follow his style. Heidegger's "Dasein" not only has heard the voice of its conscience and followed its orders, but also has become others' conscience in the same manner. There is no end to this process of becoming what we are not based on the possibilities that our circumstances give us. There is only the awareness of this process of becoming, a process which is in fact the placebo effect of a first cause, or a placebo, which is our very voice of conscience in trying to awaken us to our situation. Walt comes to this recognition through his mentor and runs his existential quest in a never-ending process. One may ask what the use of such existential quest is. And one may answer that the use of an existential quest in life is to understand human existence in an artistic way. Walt manifests human "potentiality-for-being" in the existential sense that Heidegger delineates, that is, in an artistic way in so far as living authentically in the face of contingent death is artistic. 


\section{Bibliography}

Alawneh, F.W. 2013. Existential nihilism revisited in selected novels of Paul Auster. Master's dissertation, Yarmouk University, Jordan.

Álvarez, M.L.A. 2014. The invention of the space of literature: Paul Auster's fictionalization of Maurice Blanchot's poetics. Master's dissertation, Autonomous University of Madrid, Spain.

- 2016. Paul Auster and the influence of Maurice Blanchot. Jefferson, North Carolina: McFarland and Company, Inc.

Auster, P. 2005. Collected prose: Autobiographical writings, true stories, critical essays, prefaces and collaborations with artists. New York: Picador.

- 1994. Mr Vertigo. London: Faber and Faber Ltd.

Auster, P. and Coetzee, J.M. 2014. Here and now: Letters 2008-2011. London: Vintage Books.

Auster, P. and Siegumfeldt, I.B. 2017. A life in words: Conversations with Paul Auster. New York: Seven Stories Press.

Barone, D. 1995. Introduction: Paul Auster and the postmodern American novel. In Beyond the red notebook, ed. D. Barone, 1-26. Philadelphia: University of Pennsylvania Press.

Baskin, J.R., ed. 2011. The Cambridge dictionary of Judaism and Jewish culture. Cambridge: Cambridge University Press.

Blackham, H.J. 2002. Six existentialist philosophers. New York: Routledge.

Brown, M. 2007. Paul Auster. Manchester: Manchester University Press.

Cox, G. 2008. The Sartre dictionary. New York: Continuum.

Dahlstrom, D.O. 2013. The Heidegger dictionary. London: Bloomsbury.

De Cortanse, G. 1997. La solitude du labyrinthe: Essai et entretiens. Paris: Actes Sud.

Deshmukh, P. 2014. Then catastrophe strikes: Reading disaster in Paul Auster's novels and autobiographies. PhD dissertation, Université Paris-Est, Paris.

Donovan, C. 2005. Postmodern counternarratives: Irony and audience in the novels of Paul Auster, Don DeLillo, Charles Johnson, and Tim O'Brien. New York: Routledge.

Drabble, M., ed. 2000. The Oxford companion to English literature (6th ed.). Oxford: Oxford University Press.

Exell, J.S. 1892. Homiletical commentary on the Book of Genesis. New York: Funk \& Wagnalls.

Gensini, G.F., Conti, A.A. and Conti, A. 2005. Past and present of What Will Please the Lord: An updated history of the concept of placebo. Minerva Medica: A Journal on Internal Medicine 96(2): 121-124.

Heidegger, M. 2001. Being and time, trans. J. Macquarrie and E. Robinson. Oxford: Basil Blackwell.

Hutchisson, J.M., ed. 2013. Conversations with Paul Auster. Jackson, MS: University Press of Mississippi.

Jopling, D.A. 2008. Talking cures and placebo effect. Oxford: Oxford University Press.

Martin, B. 2008. Paul Auster's postmodernity. New York: Routledge.

Michelman, S. 2008. Historical dictionary of existentialism. Toronto: The Scarecrow Press, Inc. 
Mulhall, S. 2003. Inheritance and originality: Wittgenstein, Heidegger, Kierkegaard. Oxford: Clarendon Press.

Oxford Dictionaries Online. n.d. Placebo. https://en.oxforddictionaries.com/definition/ placebo (accessed 17 October 2018).

Spinoza, B. 1992. The ethics: Treatise on the emendation of the intellect and selected letters, trans. S. Shirley. Indianapolis, IN: Hackett.

The Free Dictionary Online. n.d. Placebo effect. http://www.thefreedictionary.com/ placebo+effect (accessed 17 October 2018).

Van der Vlies, A.E. 1998. In search of self: Explorations of identity in the work of Paul Auster. Master's dissertation, Rhodes University, South Africa.

Varvogli, A. 2001. The world that is the book: Paul Auster's fiction. Liverpool: Liverpool University Press. 